\title{
SISTEM PAKAR DIAGNOSA PENYAKIT DAN HAMA PADA TANAMAN JERUK NIPIS MENGGUNAKAN METODE FORWARD DAN BACKWARD CHAINNING BERBASIS VISUAL BASIC 6.0
}

\author{
Suyono, Rina Wati, Tri Susilowati \\ Prodi Sistem Informasi STMIK Pringsewu Lampung \\ Jl. Wisma Rini No. 09 pringsewu Lampung \\ yono.psw@gmail.com \\ rinastmik12@gmail.com \\ trisusilowati423@gmail.com
}

\begin{abstract}
ABSTRAK - Setiap tanaman pastinya memiliki musuh yang dapat menghambat maupun menurunkan kualitas tanaman, tak terkecuali pada tanaman jeruk nipis. Dalam membudidayakan tanaman bukan hanya sebatas menanam dengan baik dan benar saja, namun ada beberapa hal yang di perhatikan agar perawatan atau membudidayakan dapat berjalan dengan cukup baik sehingga menghasilkan kualitas yang optimal, serangan hama maupun penyakit merupakan halangan terbesar bagi para petani karena dapat menghambat pertumbuhan maupun menurunkan kualitas tanaman tersebut, sehingga diperlukan suatu sistem yang mempunyai kemampuan seperti seorang pakar mengenai diagnosa penyakit dan hama pada tanaman jeruk nipis. Dirancangnya sistem pakar menggunakan metode Inferensi Forward Chaining dan Backward Chaining yang berbasis Visual Basic 6.0, dimaksudkan untuk membantu para petani kebun mengatasi persoalan penyakit dan hama tanaman jeruk nipis.
\end{abstract}

\section{Kata Kunci : Sistem Pakar, Tanaman Jeruk Nipis, Forward and Backward Chaining, Visual Basic 6.0}

\section{PENDAHULUAN}

\subsection{Latar Belakang Masalah}

Jeruk nipis dengan nama ilmiah Citrus Aurantifolia adalah jenis tanaman yang masuk dalam suku jeruk-jerukan ini banyak tumbuh dan tersebar di daerah Indonesia, Mexico, India dan Florida. Tumbuhan ini dapat tumbuh hingga ketinggian 3-6 meter, yang setiap cabangnya ditumbuhi duri-duri, dengan tekstur buah yang lonjong berwarna hijau sampai kuning dan tangkai daun bersayap kecil, disamping itu jeruk nipis juga merupakan sumber antioksidan yang sangat baik dengan mencegah atau menghentikan kerusakan yang disebabkan oleh radikal bebas, atau bahan kimia yang membahayakan sel-sel dalam tubuh manusia. Menurut Muthia NS (2014), Jeruk nipis juga diketahui memiliki potensi menurunkan resiko penyakit dislipidemia dengan meningkatkan kadar kolesterol HDL[1].

Dalam pertanian, hama adalah organisme pengganggu tanaman yang menimbulkan kerusakan secara fisik, sedangkan penyakit tanaman adalah sebuah kondisi dimana tanaman tersebut terganggu ataupun terhambat yang mana penyebabnya bukan berasal dari hama. Menurut T Yulianti (2013), Dalam pertumbuhan dan perkembangannya tanaman jeruk nipis tidak lepas dari penyakit dan hama, perkembangan penyakit dapat dihambat oleh endofit karena adanya sidefor atau senyawa metabolit yang beracun bagi potagon[2].

Maka diperlukan sebuah sistem pakar untuk mengetahui penyakit dan hama yang menyerang tanaman ini dengan cara mengidentifikasi atau mendiagnosa dalam sebuah rancangan aplikasi.

\subsection{Rumusan Masalah}

1. Kriteria apa saja yang di ambil dalam mendiagnosa penyakit dan hama yang menyerang tanaman jeruk nipis?

2. Bagaimana merancang bangun aplikasi sistem pakar untuk mendiagnosa penyakit dan hama pada tumbuhan jeruk nipis menggunakan program Visual Basic 6.0?

\subsection{Tujuan dan Manfaat Penelitian} berikut:

Tujuan membuat penelitian ini adalah sebagai

1. Membuat sebuah sistem pakar yang menerapkan kemampuan menyelesaikan masalah seperti layaknya seorang pakar (Human Expert).

2. Sistem pakar yang akan di bangun ini berbasis program Visual Basic 6.0 (desktop) dengan harapan dapat mudah digunakan oleh seluruh kalangan yang membutuhkan.

Manfaat penelitian ini adalah sebagai berikut:

1. Mempermudah petani atau masyarakat dalam mengidentifikasi penyakit dan hama pada tanaman jeruk nipis

2. Dengan adanya aplikasi sistem pakar petani atau masyarakat tidak harus mencari seorang pakar untuk mendiagnosa tanaman jeruk nipisnya

\section{LANDASAN TEORI}

2.1. Sistem Pakar

Menurut Sri Wahyuni (2017), Sistem pakar

(Expert System) merupakan cabang dari kecerdasan 
buatan (Artificial Intelligence) dan juga merupakan bidang ilmu yang muncul seiring perkembangan ilmu komputer saat ini[3]. Menurut Dito (2016), Sistem pakar merupakan sistem komputer yang dirancang agar dapat melakukan penalaran seperti layaknya seorang pakar pada suatu bidang keahlian tertentu. Sistem pakar diciptikan bukan untuk menggantikan kedudukan seorang pakar tetapi untuk memasyarakatkan pengetahuan dan pengalaman pakar tersebut untuk orang banyak[4]. Encep menyebutkan (2014), Komponen dalam sistem pakar adalah sebagai berikut[5]:

1. User Interface (Antarmuka Pengguna) merupakan mekanisme yang digunakan oleh pengguna dan sistem pakar untuk berkomunikasi.

2. Basis Pengetahuan mengandung pengetahuan untuk pemahaman, formulasi, dan penyelesaian masalah.

3. Akuisi Pengetahuan adalah akumulasi, transfer dan transformasi keahlian dalam menyelesaikan masalah dari sumber pengetahuan ke dalam program komputer.

4. Mesin Inferensi adalah program komputer yang memberikan metodologi untuk penalaran tentang informasi yang ada dalam basis pengetahuan dan dalam workplace, dan untuk memformulasikan kesimpulan.

5. Workplace merupakan area dari sekumpulan memori kerja (Working Memory).

6. Fasilitas Penjelasan adalah komponen tambahan yang akan meningkatkan kemampuan system pakar.

7. Perbaikan Pengetahuan - pakar memiliki kemampuan untuk menganalisi dan meningkatkan kinerja serta kemampuan untuk belajar dari kinerja.

\subsection{Forward Chainning}

Menurut Bambang (2008), Forward Chainning. Pencocokan fakta atau pernyataan dimulai dari bagian sebelah kiri (IF dulu). Dengan kata lain, penalaran dimulai dari fakta terlebih dahulu untuk menguji kebenaran hipotesis[6].

\subsection{Backward Chainning}

Menurut Bambang (2008), Backward Chainning. Pencocokan fakta atau pernyataan dimulai dari bagian sebelah kanan (THEN dulu). Dengan kata lain, penalaran dimulai dari hipotesis terlebih dahulu, dan untuk menguji kebenaran hipotesis tersebut harus dicari fakta-fakta yang ada dalam basis pengetahuan[7].

\subsection{Morfologi Tanaman Jeruk Nipis}

Menurut Budi (2016), Jeruk nipis (Citrus Aurantifolia) termasuk salah satu jenis citrus jeruk. Tanaman jeruk nipis mempunyai akar tunggang. Jeruk nipis termasuk jenis tumbuhan perdu yang memiliki dahan dan ranting. Batang pohonnya berkayu ulet dan keras, sedangkan permukaan kulit hanya berwarna tua dan kusam. Daunnya majemuk, berbentuk elips dengan pangkal membulat, ujung tumpul dan tepi beringgit. Panjang daunnya mencapai 2,5-9 cm dan lebarnya 2-5 $\mathrm{cm}$. Tulang daunnya menyirip dengan tangkai bersayap hijau dan lebar 5-25mm[8].

\subsection{Visual Basic 6.0}

MM Amin menjelaskan dalam buku Dasar Visual Basic 6.0 (2014), Visual Basic adalah salah satu produk bahasa pemrograman yang dikeluarkan Microsoft, salah satu perusahaan softwareterkemuka di dunia. Visual basic 6.0 merupakan bahasa pemrograman yang mudah digunakan untuk pengembangan aplikasi, baik itu aplikasi kecil maupun aplikasi besar. Dengan banyaknya komponen kontrol yang disediakan oleh visual basic 6.0, membuat para programmer dan pengembang aplikasi lebih mudah dalam pembuatan aplikasi[9].

\section{METODE PENELITIAN}

\subsection{Analisis Kebutuhan}

Usman mengatakan (2017), Sistem pakar yang dibangun ini merupakan suatu sistem informasi yang berbasis komputer dengan memanfaatkan teknologi kecerdasan buatan (Artificial Intelligence)[10]. Yang berfungsi sebagai sistem alat bantu atau pemberi saran maupun rekomendasi dari proses konsultasi penyakit dan hama kepada pengguna, sehingga pengguna mengetahui masalah yang menyerang tanaman jeruk nipis. Konsultasi yang dihasilkan oleh sistem ini dilengkapi dengan penyebab, gejala, keterangan, dan pengendaliannya.

\subsection{Rancangan Proses}

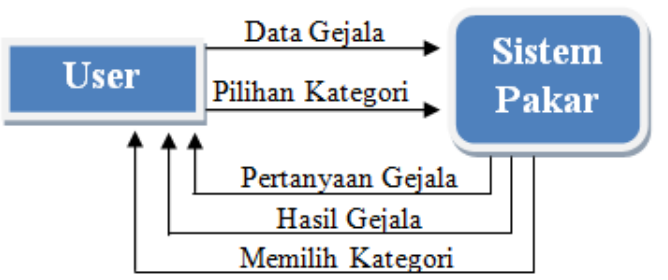

Gambar 1. DFD Level 0

\subsection{Proses Pelacakan}

Dalam Penelitian yang dilakukan oleh Dede (2016), Proses pelacakan yang digunakan dalam sistem ini mengikuti pola pelacakan maju (Forward Chainning)[11]. Pada identifikasi penyakit dan hama, proses pelacakan maju dimulai dengan memberikan pertanyaan tentang bagian apa yang terserang penyakit atau hama, kemudian dari fakta yang dimasukkan akan diperoleh kesimpulan tentang nama penyakit atau dapat diperoleh nama hama, keterangan, dan pengendaliannya.

\subsection{Representasi Pengetahuan}

Dalam penelitian ini basis pengetahuan direpresentasikan dengan menggunakan IF-THEN. Berikut contoh: if daun mengkerut and daun menggulung and daun rontok then diagnosis: Ulat Peliang Daun (Hama), diikuti informasi gejala, keterangan, dan penanggulangan. 
Untuk memudahkan penulisan dalam tabel maka diketahui Gejala (G) dan Penyakit (P) dengan rincian sebagai berikut:

Gejala Daun

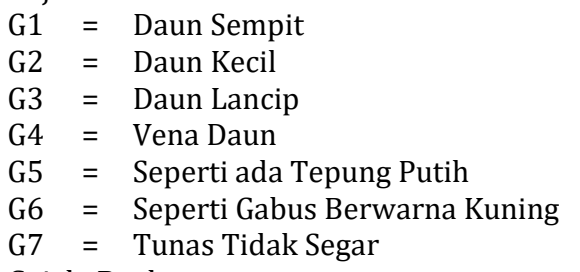

Gejala Buah

$\mathrm{G8}=$ Buah Kecil

G9 = Buah Asam

$\mathrm{G} 10=$ Biji Rusak

G11 = Pangkal Buah Berwarna Oranye

G12 = Seperti Gabus Berwarna Kuning

G13 = Tepung Berwarna Hijau Biru

G14 = Buah Selalu Gugur

Gejala Tangkai

G15 = Lekuk Batang Kaku dan Pucat

G16 = Pertumbuhan Terhambat

$\mathrm{G} 17=$ Muncul Gom

G18 = Tangkai Berwarna Keabu-abuan

G19 = Kulit Kering dan Mengelupas

G20 = Seperti ada Tepung Putih

G21 = Seperti Gabus Berwarna Kuning

G22 = Tangkai Kering

G23 = Retakan Melintang

G24 = Kering dan Sulit Dikelupas

Penyakit

$\mathrm{P} 1=\mathrm{CVPD}$

$\mathrm{P} 2=$ Tristeza

$\mathrm{P3}=$ Blendok

P4 = Embun Tepung

$\mathrm{P} 5=$ Kudis

P6 = Busuk Buah

P7 = Busuk Akar dan Pangkal Batang

P8 = Buah Gugur Prematur

P9 = Jamur Upas

Tabel 1. Hubungan Gejala dengan Penyakit Tanaman Jeruk Nipis

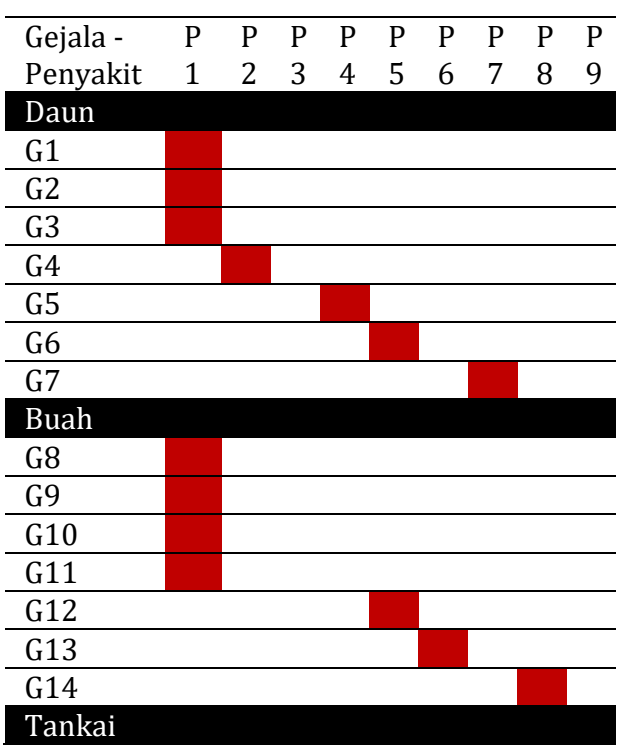

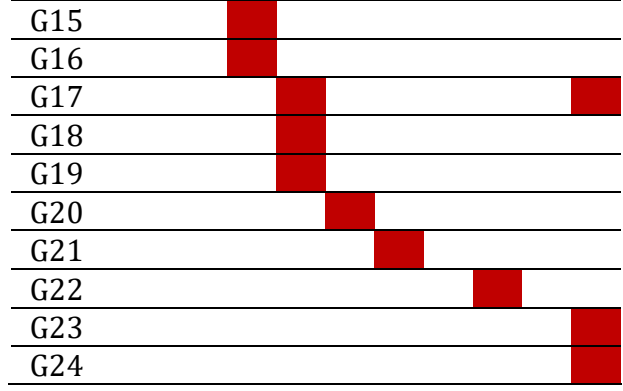

Untuk memudahkan penulisan dalam tabel maka diketahui Gejala (G) dan Hama $(\mathrm{H})$ dengan rincian sebagai berikut:

Gejala Daun

$\mathrm{G1}=$ Daun Menggulung

$\mathrm{G} 2=$ Daun Mengkerut

$\mathrm{G} 3=$ Daun Rontok

$\mathrm{G} 4=$ Bercak Kuning/Coklat

$\mathrm{G5}=$ Bercak Coklat Kehitaman

G6 = Daun Menebal

G7 = Tepi Daun Menggulung Keatas

G8 = Ujung Tunas Menjadi Hitam

G9 = Kering dan Gugur

G10 = Bekas Luka Warna Coklat Keabu-abuan

G11 = Daun Berwarna Kuning

G12 = Bercak Kholorotis

G13 = Daun Gugur

Gejala Buah

G14 = Bercak Keperak-perakan

$\mathrm{G} 15=$ Bercak Coklat

G16 = Lubang yang Mengeluarkan Getah

G17 = Keluarnya Cairan Buah

G18 = Mudah Gugur Sebelum Tua

$\mathrm{G} 19=$ Buah Gugur

G20 = Lubang Kecil Dibagian Tengah

$\mathrm{G} 21=$ Belatung Kecil Didalam Buah

Gejala Bunga

G22 = Bunga Mudah Rontok

Gejala Tangkai

G23 = Berkas Berwarna Kuning

G24 = Tangkai Mengering

G25 = Kulit Tangkai Retak

G26 = Ranting Muda Terkadang Mati

Hama

$\mathrm{H} 1=$ Kutu Daun

$\mathrm{H} 2=$ Ulat Peliang Daun

$\mathrm{H} 3=$ Tungau

$\mathrm{H} 4=$ Penggerek Buah

H5 = Kutu Penghisap Daun

H6 = Ulat Penggerek Bunga dan Puru Buah

$\mathrm{H} 7=$ Thrips

H8 = Kutu Dompolan

H9 = Lalat Buah

H10 $=$ Kutu Sisik

$\mathrm{H} 11=$ Kumbang Belalai 
Tabel 2. Hubungan Gejala dengan Hama Tanaman Jeruk Nipis

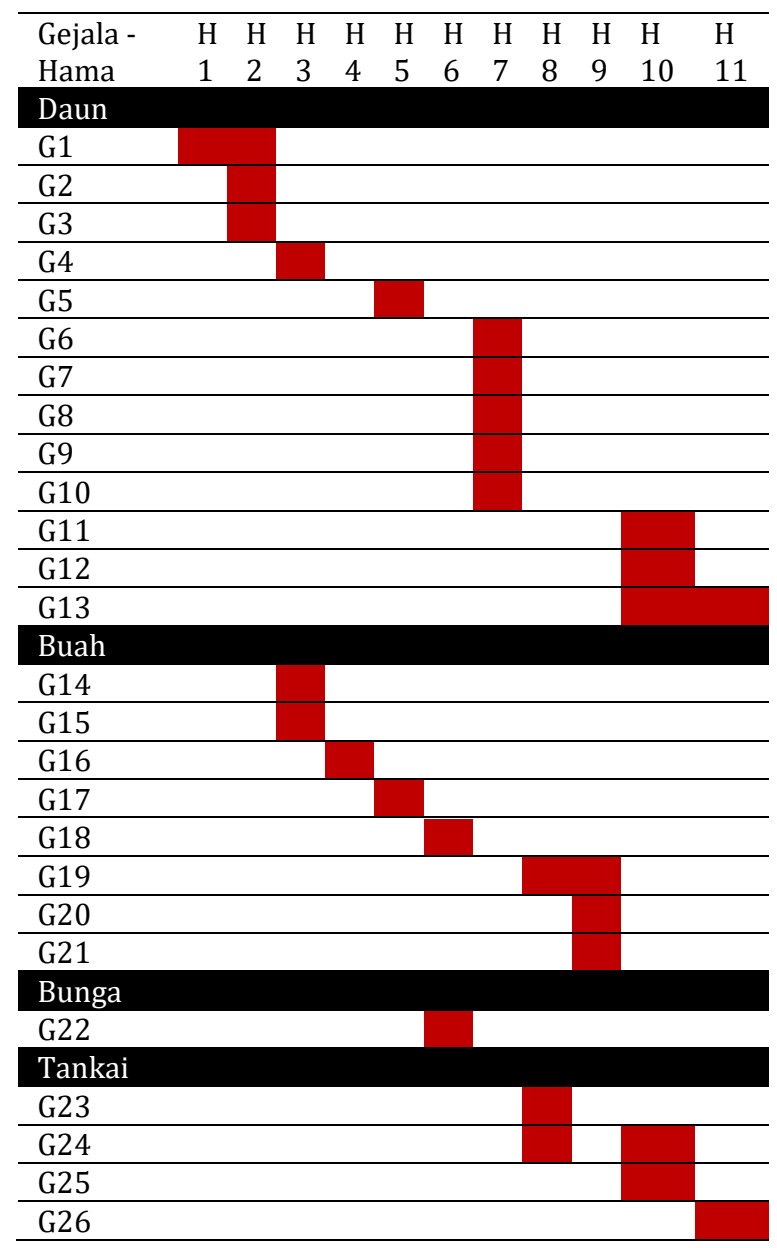

\section{HASIL DAN PEMBAHASAN}

Dalam aplikasi sistem pakar akan mengidentifikasi dan mempunyai keluaran berupa nama penyakit bisa juga diperoleh nama hama, penyebab, keterangan, dan pengendaliannya. Pada pilihan identifikasi akan di bagi beberapa kelompok bagian pada tanaman jeruk nipis sesuai dengan apa yang diserang yaitu daun, buah, bunga, tangkai sebagai menu utamanya.

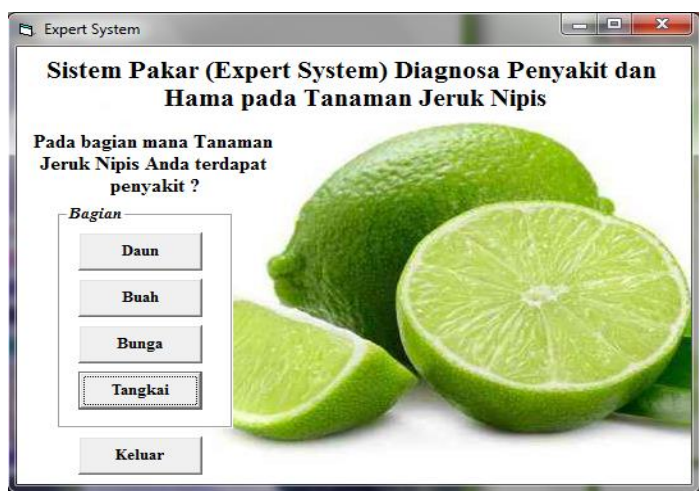

Gambar 2. Menu Utama, pilihan bagian pada tanaman
Contoh kasus 1:

Identifikasi dan hasil diagnosa pada bagian: Daun Dengan ciri-ciri:

Daun Sempit

Daun Kecil

Daun Lancip

Hasil Diagnosa:

CVPD

Berikut tampilan untuk identifikasi dan hasilnya pada gambar berikut:

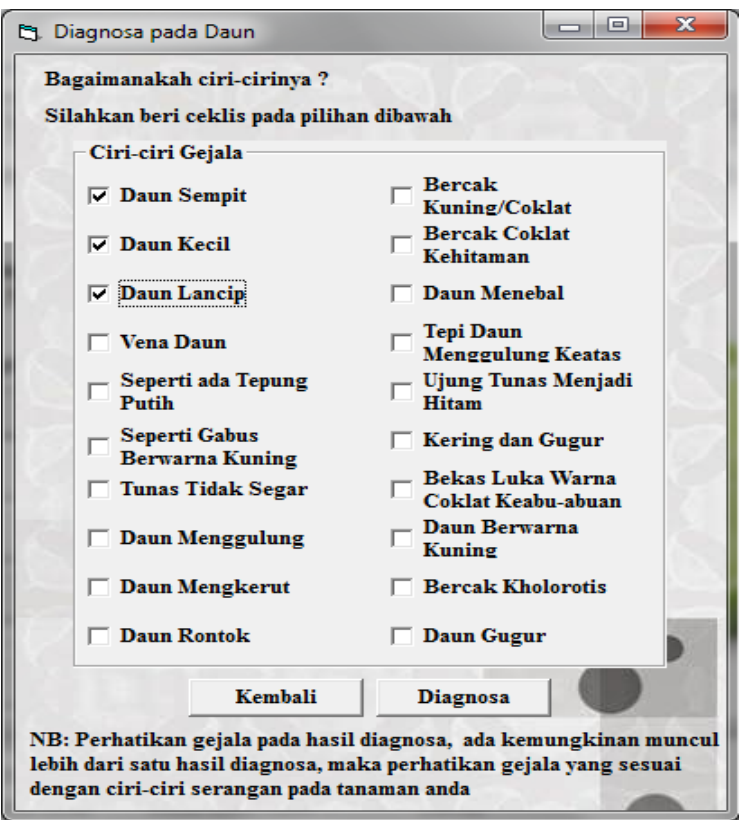

Gambar 3. Input beberapa ciri Gejala

Hasil Diagnosa: Penyakit

CVPD (Citrus Vein Phloem Degeneration)

Penyakit ini disebabkan oleh Bacterium Like Organism dengan vector kutu loncat Diaphorina Citri. Penyakit ini menyerang tanaman pada bagian silinder pusat (phloem) batang.

Gejala yang terlihat daun sempit, kecil, lancip, buah kecil, asam, biji rusak dan pangkal buah oranye

\section{Cara Pengendalian}

Untuk pengendalian pada penyakit dapat dilakukan dengan gunakan tanaman sehat bebas CVPD, selain itu penempatan lokasi kebun minimal $5 \mathrm{~km}$ dari kebun yang terserang CVPD. Gunakan insektisid untuk vector dan perhatikan sanitasi kebun yang baik.

\section{Gambar 4. Hasil diagnosa}

Contoh kasus 2:

Identifikasi dan hasil diagnosa pada bagian: Buah

Dengan ciri-ciri:

Buah Kecil

Buah Asam

Biji Rusak

Pangkal Buah Berwarna Oranye

Hasil Diagnosa: 
CVPD

Berikut tampilan untuk identifikasi dan hasilnya pada gambar berikut:

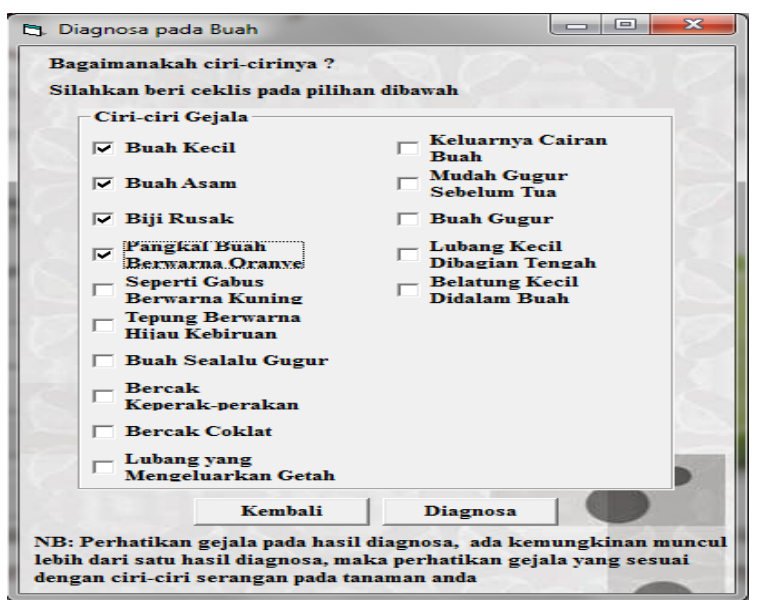

Gambar 5. Input beberapa ciri Gejala

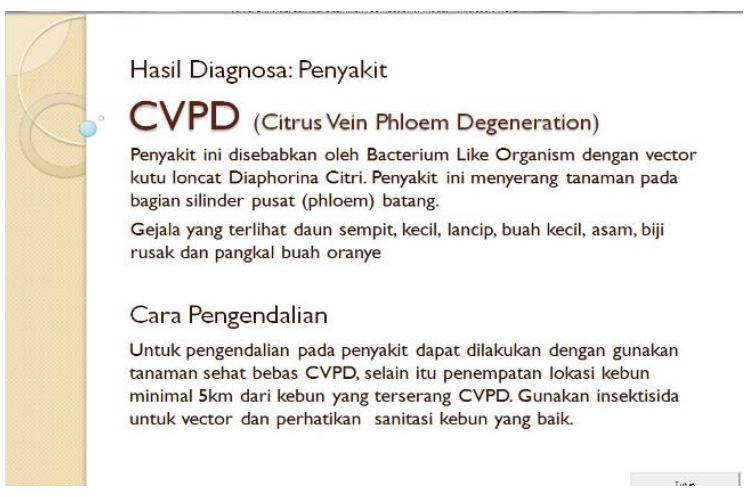

Gambar 6. Hasil diagnosa

Contoh kasus 3:

Identifikasi dan hasil diagnosa pada bagian: Bunga Dengan ciri-ciri:

Bunga Mudah Rontok

Hasil Diagnosa:

Ulat Penggerek Bunga Dan Puru Buah

Berikut tampilan untuk identifikasi dan hasilnya pada gambar berikut:

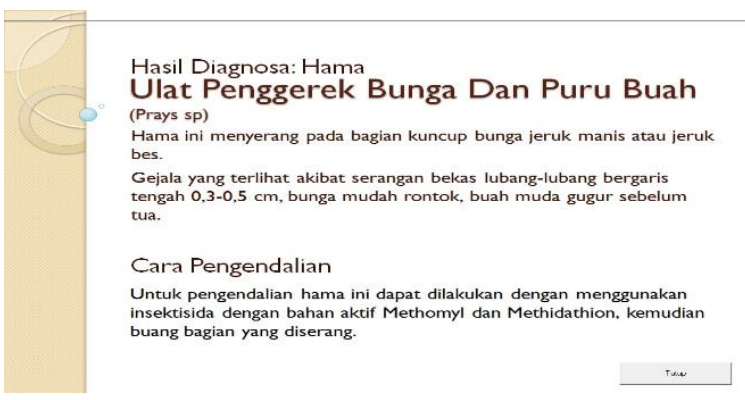

Gambar 7. Hasil diagnosa

\section{Contoh kasus 4:}

Identifikasi dan hasil diagnosa pada bagian: Tangkai

Dengan ciri-ciri:

Lekuk Batang kaku dan Pucat

Pertumbuhan Terhambat

Hasil Diagnosa:

Tristeza

Berikut tampilan untuk identifikasi dan hasilnya pada gambar berikut:

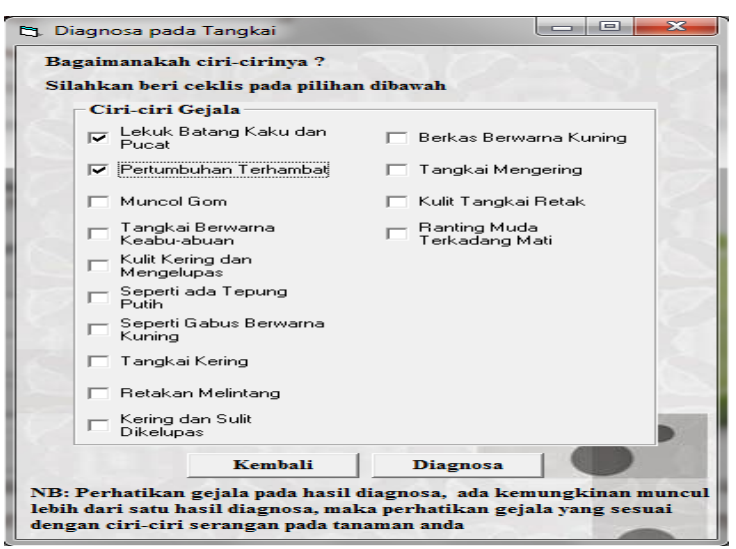

Gambar 8. Input beberapa ciri Gejala

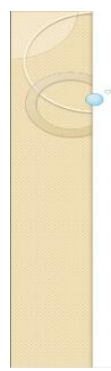

Hasil Diagnosa: Penyakit

Tristeza

Penyakit ini disebabkan oleh virus Citrus Tristeza dengan vector
Toxoptera. Untuk bagian yang terserang jeruk manis, nipis, besar dan batang bawah jeruk Japanese Citroen.

Gejala yang terlihat akibat serangan, lekuk batang daun kaku

Cara Pengendalian

Untuk pengendalian pada penyakit ini dapat dilakukan sanitasi kebun. memusnahkan tanaman yang terserang, dan dengan menggunakan

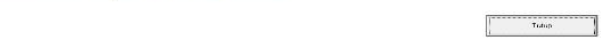

\section{Gambar 9. Hasil diagnosa}

\section{KESIMPULAN DAN SARAN}

\subsection{KESIMPULAN}

Berdasarkan dari hasil penelitian dan pembahasan, maka penulis menarik kesimpulan dalam mencapai tujuan yang diinginkan. Adapun kesimpulan yang dapat diambil adalah sebagai berikut:

1. Penelitian ini Menghasilkan diagnosa penyakit dan hama pada tanaman jeruk nipis dengan mendiagnosa kriteria-kriteria yang dipilih.

2. Penelitian ini juga menghasilkan suatu program aplikasi untuk mendiagnosa penyakit dan hama pada tanaman jeruk nipis menggunakan Pemrograman Visual Basic 6.0.

\subsection{SARAN}

Program sistem pakar ini perlu dilakukan evaluasi sehingga dapat dilihat apakah perlu adanya perbaikan atau penyempurnaan kembali dan pengetahuan yang terdapat dalam basis pengetahuan sistem pakar ini terbatas pada penyakit dan hama tanaman jeruk nipis, penulis menyarankan agar 
pengembang sistem pakar selanjutnya tidak terbatas pada tanaman jeruk nipis saja.

\section{Daftar PUSTAKA}

[1] Syadza, Muthia Nada. 2014. Pengaruh Pemberian Jus Pare (Momordica Charantia Linn.) dan Jus Jeruk Nipis (Citrus Aurantifolia) Terhadap Peningkatan Kadar Kolesterol HDL (High Density Lipoprotein) Tukus Sprague Dawley Dislipidemia. Universitas Diponegoro:Semarang.

[2] Yulianti, Titiek. 2013. Pemanfaatan Endofit Sebagai Agnesia Pengendali Hayati Hama dan Penyakit Tanaman. Buletin Tanaman Tembakau, Serat \& Minyak Industri 5(1), April 2013:40-49. Balai Penelitian Tanaman Pemanis dan Serat:Malang.

[3] Nasution, Sri Wahyuni. Hasibuan, Nelly Astuti. Ramadhani, Putri. 2017. Sistem Pakar Diagnosa Anoreksia Nervosa Menerapkan Metode Case Based Reasoning. KOMIK (Konferensi Nasional Teknologi Informasi dan Komputer). Volume 1, Nomor 1, Oktober 2017. STMIK Budi Darma:Medan.

[4] Utomo, Dito Putro. Nasution, Surya Darma. 2016. Sistem Pakar Mendeteksi Kerusakan Toner Dengan Menggunakan Metode Case Based-Reasoning. Jurnal Riset Komputer (JURIKOM). Volume: 3, Nomor: 5, Oktober 2016. STMIK Budidarma:Medan.

[5] Aziz, Encep Fuad. Damiri, Dhami Johar. Destiani, Dini. 2014. Perancangan Sistem Pakar Diagnosis
Penyakit Syaraf Pada Wajah Berbasis Web. Sekolah Tinggi Teknologi:Garut.

[6]. Yuwono, Bambang. Fauziah, Yuli. Setyaningsih, Yenny Rachma. 2008. Sistem Pakar Berbasis Web Untuk Identifikasi Jenis dan Penyakit pada Bunga Mawar. Seminar Nasional Informatika 2008 (semnasIF 2008). UPN "Veteran":Yogyakarta

[7] Yuwono, Bambang. Fauziah, Yuli. Setyaningsih, Yenny Rachma. 2008. Sistem Pakar Berbasis Web Untuk Identifikasi Jenis dan Penyakit pada Bunga Mawar. Seminar Nasional Informatika 2008 (semnasIF 2008). UPN “Veteran”:Yogyakarta

[8] Santoso, Budi. 2016. Pemanfaatan Jeruk Nipis Sebagai Elektrolit dalam Sel Volta.

[9] Amin, Muhammad Miftakul. 2014. Dasar Pemrograman Visual Basic 6.0. Politeknik Negeri Sriwijaya:Palembang.

[10] Samsudin. Usman. Selviana. 2017. Applikasi Sistem Pakar Diagnosa Penyakit Pernapasan Menggunakan Metode Case-Based Reasoning. Jurnal IPTEKS TERAPAN. Research of Applied Science and Education V11.i3 (272-282). Universitas Islam Indragiri:Tembilahan.

[11] Abdurahman, Dede. Prasetyo, Tri Perga. 2016. Mengukur Tingkat Kepuasan Mahasiswa Dalam Pembelajaran Dengan Menggunakan Sistem Pakar. Jurnal J-Ensitec: Vol 02 | No. 02, Mei 2016. Fakultas Teknik Universitas Majalengka:Majalengka.

[12] Nugraha, Deny Wiria. 2014. Sistem Pakar Untuk Mendiagnosa Kerusakan Perangkat Televisi Menggunakan Metode Backward Chaining. INFORMATIKA Vol. 10 No. 2, Tahun 2014. 